\title{
Probing the physiological state of phytoplankton at the single-cell level*
}

\author{
FRANK J. JOCHEM
}

The University of Texas at Austin, Marine Science Institute, 750 Channel View Drive, Port Aransas, TX 78373, USA.

Fax: (361) 749 6777. E-Mail: frank@emcs.de

\begin{abstract}
SUMMARY: Probing the physiological state of phytoplankton at the single-cell level provides valuable insight in ecological studies as well as in environmental monitoring of pollution or UV impacts. This paper reviews the recent progress in assessing the physiological state of phytoplankton with flow cytometry by inherent cell properties such as cell size and chlorophyll autofluorescence, specific fluorescent dyes, and newly developed molecular probes and enzyme substrates. It is reported how nitrogen and iron limitation as well as the effect of copper pollution could be derived from changes in cell inherent properties. Effects of $\mathrm{Cu}$ were also recorded by monitoring cell membrane potentials and esterase activity. Photosynthetic capacity of algae was assessed by changes in chlorophyll fluorescence with the electron transport inhibitor DCMU, by a cytometric adaptation of the pump-and-probe approach, and molecular probes for Rubisco. Antibodies were also applied to mark non-terminal stages in the cell DNA replication cycle, to detect non-proliferating cells, to assess DNA damage caused by UV-B radiation and to quantify diatom stickiness. Fluorescein diacetate proved useful to discriminate metabolically active from inactive cells and to reveal strategies of dark survival in algae. The activity of alkaline phosphatase was recorded by a new fluorigenic substrate ELF, and polyclonal antibodies against nitrate reductase (NR) provided measurements of the NR abundance. An outlook will show how recent developments in molecular probes might affect the future analysis of marine ecosystems and their communities.
\end{abstract}

Key words: flow cytometry, phytoplankton, physiology, molecular probes, fluorescent dyes.

\section{INTRODUCTION}

In times of increasing public awareness and sensitivity towards the environmental status of our oceans, reliable and conclusive biological monitoring becomes a politically as well as scientifically vital task. Changes in environmental conditions are often most easily and rapidly recognized by the reaction of unicellular organisms. Due to short generation times and a comparably simple organismic organization protists can react faster than higher organisms with

*Received May 4, 1999. Accepted January 18, 2000. high organizational complexity. Furthermore, their simple organization makes the detection of specific physiological reactions and conditions more feasible. Particularly the marine phytoplankton can serve as a valuable marker for environmental monitoring.

Environmental impacts and water pollution can affect organisms - and thereby the whole ecosystem and its functioning- although the water looks "chemically clean". To be able to detect such contamination based on physiological "properties" of the organisms will help to identify chronic environmental pollution and to provide early warning at sublethal pollution levels. 
Besides these more applied aspects a variety of questions on how aquatic systems function still remain to be resolved. Among them, basic ones such as the persistence of High Nutrient - Low Chlorophyll areas (HNLCs) where phytoplankton is unable to proliferate and deplete high ambient nutrient stocks of nitrate and potential iron limitation is discussed (Martin and Fitzwater, 1988; Martin et al., 1990), the control of nutrient uptake and regeneration kinetics in different pelagic communities, and the reaction of inter-species competition and food web dynamics on environmental conditions. More peculiar topics comprise, for example, the observation of algal accumulations in aphotic depths (Detmer et al., 1993; Murphy and Cowles, 1997) and how or if they survive, or the specific conditions that allow harmful algal blooms to develop. Altogether, there are many occasions when insight into the physiology of phytoplankton is desirable within studies of aquatic ecosystems.

The uniqueness of flow cytometry lies in the ability to perform quantitative measurements of individual cells in large numbers and appreciably short time. Application to field samples might reveal different types of physiological responses of distinguished sub-populations of the phytoplankton community not accessible by bulk measurements and may yield insight into the competitive advantage or adaptation of single algal species/groups upon specific environmental conditions.

Flow cytometry can, therefore, take advantage of directly measurable, inherent cell properties or make use of fluorescent markers for cell components or metabolic processes. New insights into community dynamics such as taxonomy, specific activity or limiting factors are nowadays possible through the development of new optical and molecular probes of individual cell physiology: quantification of cell death (Veldhuis and Kraay, 2000), reproduction (Jochem and Meyerdierks, 1999; Veldhuis and Kraay, 2000), enzyme activity, nutrient status and others.

Among fluorescent markers, static and dynamic measurements can be distinguished: static measurements refer to cell components such as DNA, proteins and chemicals within the cell or on the cell surface whose staining, once achieved, remains stable. In kinetic measurements, the staining result or fluorescence yield depends on the time of analysis and relies - in contrast to static measurements - on live cells; fluorigenic enzyme substrates that evolve fluorescence upon the activity of the studied enzyme are common examples.
The scope of this contribution is to review the present state of physiological probes available to the cytometric analysis of phytoplankton.

\section{INHERENT CELL PROPERTIES}

When flow cytometry was initially adopted from medical research to marine studies (Yentsch et al., 1983), the primary goal was the fast and reliable quantification of the newly discovered picophytoplankton, algal cells of less than $2 \mu \mathrm{m}$ in size. So far, these organisms, whose ubiquity and importance not only in oligotrophic oceans (Stockner and Antia, 1986) but also in temperate and coastal areas (Jochem, 1988, 1989) was rapidly acknowledged, were accessible only by timely microscopic analysis (Hobbie et al., 1977). Later, the advantage of flow cytometry providing cellular properties such as cell size and chlorophyll content for each individual cell measured without additional effort have also been employed for ecophysiological insights.

Cell size is derived from light scatter at low angles relative to the excitation light, commonly called Forward Angle Light Scatter (FSC). Although the refractive index, which is a function of the chemical composition, and the shape of cells might interfere with FSC measurements, FSC is commonly accepted as a relative measure of cell size, which increases linearly with the square of the cell diameter or cross section (Steen, 1991; Cunningham and Buonaccorsi 1992). Perpendicular or side-angle light scatter (SSC) reflects particle morphology and structure (Dubelaar et al., 1987; Ackelson et al., 1988). For small, picoplanktonic phytoplankton, however, SSC often provides a better measure of relative cell size because of higher sensitivity to small changes as compared to FSC. Minor differences in cell shape and morphology prevent the dependence of SSC on cell shape to bias its use as cell size proxy within this group of coccoid to ellipsoid organisms.

Chlorophyll autofluorescence, measured as red fluorescence $>610 \mathrm{~nm}$ or $>650 \mathrm{~nm}$, depending on the individual instrument setup, has proven to be linearly related to cellular chlorophyll concentrations in laser-based instruments (Li et al., 1993; Graziano et al., 1996; Veldhuis and Kraay, 2000). Changes in cellular chlorophyll fluorescence, often considered as a sign of photoadaptation to decreasing light with increasing depth in the ocean (Veldhuis and Kraay, 2000), and changes of cell size have also been used 

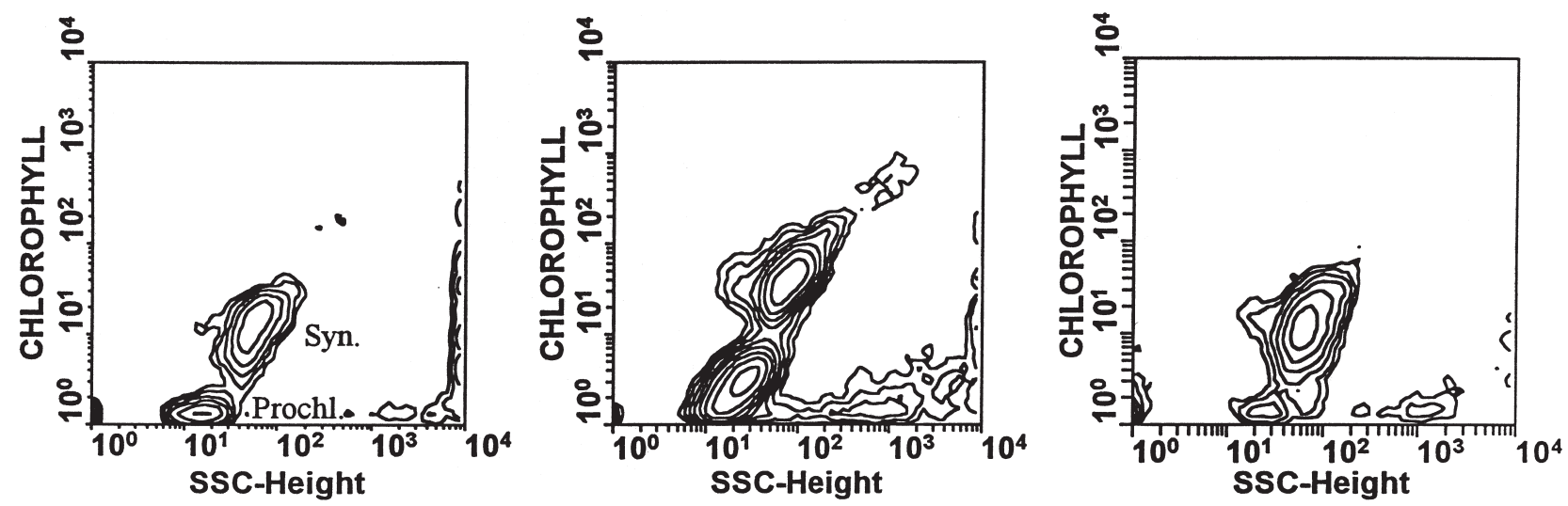

FIG. 1. - Effect of iron addition on picophytoplankton in the tropical North Atlantic, Bahamas: 2-parameter histograms of cell size (Sideangle light scatter, rel. units) vs. chlorophyll autofluorescence (rel. units). Field samples were incubated in quartz bottles in a cooled deck incubator with and without the addition of $\mathrm{Fe}(5 \mu \mathrm{M})$ in nutrient replete (f/20) conditions. (a) initial sample; (b) with Fe after 3 days; (c) without Fe after 3 days. Prochl. = Prochlorococcus sp.; Syn. = Synechococcus sp. Gelpke and Jochem, unpublished data.

to depict the physiological state of algae in nutrient or contaminant studies (Abalde et al., 1995; Cid et al., 1997).

Tightly coupled food web interactions often make it difficult to assess the potential limitation of a specific nutrient in addition experiments. In the North Atlantic, nitrate addition did result in higher cell abundance of Prochlorococcus sp. but not of Synechococcus sp.; increased cellular chlorophyll in both species, however, revealed nitrogen limitation in the latter as well (Graziano et al., 1996). Similarly, iron enrichment in the Equatorial Pacific did not result in higher abundance of phytoplankton except for pennate diatoms; all phytoplankton showed, however, increased pigment fluorescence upon iron addition (Zettler et al., 1996). In the tropical North Atlantic, cytometric assessment of cellular pigmentation also proved iron limitation of phytoplankton independent of the necessity to determine changes in actual growth rates (Fig. 1). Higher growth rates of phytoplankton due to nutrient additions might, thus, easily be masked by instantaneously higher grazing rates as well but physiological changes preserved within the single cells can be evidenced by flow cytometry.

An increase in cell volume upon copper pollution as previously reported from microscopic studies (Stauber and Florence, 1987) was cytometrically documented as an increase in FSC in Dunaliella tertiolecta (Abalde et al., 1985) and Phaeodactylum tricornutum (Cid et al., 1997). Heavy metals change the cell membrane permeability to small cations (Overnell, 1975), which may lead to the observed increase in cell volume (Cid et al., 1997). At the same time, copper induced a significant increase in chlorophyll fluorescence in P. tricornutum (Cid et al., 1996b). The inhibition of the electron flow in the photosystem II (PS2) reaction center at the donor site provokes a decrease in chlorophyll fluorescence, but inhibition at the acceptor site of PS2 will increase fluorescence (Samson et al., 1988). Cytometric records of cellular chlorophyll fluorescence increase upon copper contamination evidence that copper acts on the oxidative side of PS2 (Cid et al., 1996b). Whereas most toxicity tests on microalgae work on $96 \mathrm{hrs}$ incubation periods, the reported changes in P. tricornutum could be documented by flow cytometry within $24 \mathrm{hrs}$ after copper exposure (Cid et al., 1997).

In mercury-lamp equipped cytometers with low excitation light intensity, linearity of live chlorophyll fluorescence to chlorophyll concentration is lost. Instead, on these instruments, DCMUenhanced chlorophyll fluorescence can be used to assess the photosynthetic capacity of algal cells (Furuya and $\mathrm{Li}, 1992$ ) as has been previously applied to bulk measurements of phytoplankton (Samuelsson and Öquist, 1977). DCMU (3-(3,4dichlorphenyl)-1,1-dimethylurea) blocks the electron transport at the electron acceptor Q in PS2 and chlorophyll fluorescence is thereby maximized. The fluorescence enhancement by DCMU as compared to live fluorescence provides a measure for photosynthetic capacity. A FACS Analyzer with a mercury cadmium arc lamp provided a significant correlation between fluorescence enhancement and photosynthetic capacity as derived from ${ }^{14} \mathrm{CO}_{2}$-incubations (Furuya and Li, 1992). 
More recently, the photosynthetic apparatus of phytoplankton has been monitored by saturatingflash or "pump-and-probe" fluorescence measurements (Falkowski et al., 1991), which uses a similar principle as the DCMU approach. The fluorescence of dark-adapted cells is measured by weak "probe" flashes of chlorophyll exciting light both before $\left(\mathrm{F}_{0}\right)$ and after $\left(\mathrm{F}_{\mathrm{m}}\right)$ a saturating "pump" flash. The pump flash causes all the photosystem II (PS2) reaction centers to pass an electron to the primary electron receptor, thereby closing the PS2 to new excitement; excitations at such a reaction center have a higher probability of being re-emitted as fluorescence. For a cell with functional reaction centers, fluorescence from the second flash will be higher than from the first, and the difference (variable fluorescence, $F_{v}=$ $\left.\mathrm{F}_{\mathrm{m}}-\mathrm{F}_{0}\right)$ is related to the fraction of functional reaction centers (Olson and Zettler, 1995). $\mathrm{F}_{\mathrm{v}} / \mathrm{F}_{\mathrm{m}}$, which may range from zero to 0.65 (Falkowski et al., 1992), then represents a measure of PS2 efficiency.

Application of the "pump-and-probe" technique to oceanographic research demonstrated its usefulness to distinguish nutrient from light limitation in phytoplankton (Kolber et al., 1990, 1994; Geider et al., 1993; Kolber and Falkowski, 1993). However, since these applications are bulk measurements, they represent weighted average properties of all the fluorescent particles present in the sample. For example, an increasing proportion of detrital chlorophyll and an increasing degree in nitrogen limitation would both appear as a decrease in $\mathrm{F}_{\mathrm{v}} / \mathrm{F}_{\mathrm{m}}$ (Olson et al., 1996). Flow cytometric analyses would not only prevent such confusion of different mechanisms influencing fluorescence results but would also provide insight into the natural variability of photosynthetic capacities among different species and among individuals of the same species in a given phytoplankton assemblage.

The potential for flow cytometric measurement of photochemical energy conversion efficiency of PS2 was demonstrated with a pump-and-probe approach by Olson and Zettler (1995). The results suggested, however, that this approach is limited by sensitivity problems associated with the low excitation intensity required for probing. Instrumental improvements comprised the addition of an infrared laser to trigger particle detection, whose wavelength does not interfere with PS2 activity, splitting the 488 nm laser into a high pump and low probe beam, and elongating the $488 \mathrm{~nm}$ laser spot for extended fluorescence measurement during passage time of the cells. Eventually, these instrumental modifications improved sensitivity and lead to a "pump-duringprobe" approach. Instead of direct measurements of $\mathrm{F}_{0}$ and $\mathrm{F}_{\mathrm{m}}$, fluorescence emission from each single particle is recorded over time scales of 100-250 $\mu \mathrm{s}$ during its passage through the elongated $488 \mathrm{~nm}$ laser spot (Olson et al., 1996, 1999). This system demonstrated that photosynthesis of pennate diatoms in the Southern Ocean was iron limited but that of cryptophytes was not (Olson et al., 1999). Still, this system is limited by sensitivity to the analysis of cells $>2 \mu \mathrm{m}$ (Olson et al., 1999), which would prevent its application in picoplankton dominated warm ocean regions. Time-resolved photon counting, however, provided reliable measurements on the photosynthetic system of the smallest known phytoplankton, Prochlorococcus marinus (Olson et al., 1996).

\section{FLUORESCENT DYES FOR CELL CONSTITUENTS: STATIC MEASUREMENTS I}

One of the most prominent and periodically changing constituents of living cells is the set of nuclear DNA, which undergoes replication and eventually doubling prior to cell division. A variety of specific dyes for double-stranded DNA have been successfully applied in flow cytometry to assess cell cycle stages and to derive in-situ growth rates (Jochem and Meyerdierks, 1999). For a detailed description of present achievements in cytometric cell cycle analysis, the reader is referred to Veldhuis and Kraay (2000) in this volume.

Cytometric application of $\mathrm{DiOC}_{6}$ (3,3-dihexyloxacarbocyanine) and rhodamine-123 revealed changes in cell membrane and mitochondrial membrane potentials upon copper exposure in the marine diatom Phaeodactylum tricornutum (Cid et al., 1995, 1996a). Both membrane potentials increased with copper concentration, detectable $96 \mathrm{hrs}$ after $\mathrm{Cu}$ exposure. Copper concentrations $>0.1 \mathrm{mg} \mathrm{l}^{-1}$ induced degenerative processes in $P$. tricornutum related to disorders in membrane systems (Cid et al., 1996a) and $10 \mathrm{mg} \mathrm{Cu}^{-1}$ provoked an acute increase in intracellular $\mathrm{pH}$ as evidenced from cytometric measurement of DCF (2,7-dichlorofluorescein; Cid et al. 1995).

The effects of mercury and cadmium on the intracellular level of nonproteinaceous thiols in the unicellular green alga Tetraselmis tetrathele were monitored by the fluorescent dye 5-chloromethylfluorescein (Satoh et al., 1999). Fluorescence inten- 
sity within the cells was reduced by exposure to $>3$ $\mu \mathrm{M} \mathrm{HgCl}_{2}$ but not by exposure to $\mathrm{CdCl}_{2}$ at concentrations of up to $1.0 \mathrm{mM}$. Depletion of nonproteinaceous thiols began within $30 \mathrm{~min}$ after mercury exposure, and cells were completely deprived of thiols after 2 hrs.

Other specific dyes for cell constituents such as Calcofluor White, which stains cellulose fibers and is used in dinoflagellate taxonomy (e.g. Fritz and Triemer, 1985; Jensen and Moestrup, 1997), or lipid stains such as Neutral Red and Nile Red were hitherto not exploited in flow cytometry although common in histochemistry and fluorescence microscopy.

\section{MOLECULAR PROBES FOR CELL CONSTITUENTS: STATIC MEASUREMENTS II}

The majority of molecular probes for static measurements of cell constituents and physiological status relies on the visualization of antigen-antibody reactions. The basic principle is the binding of the specific antibodies to the target of interest and subsequent visualization. The result of static measurements is, therefore, dependent on the concentration of the target antigen within the cell and the efficiency of antibody binding and antibody visualization.

Visualization can be achieved by using either fluorescently labelled antibodies, i.e. the antibody is bound to a fluorescent dye such as FITC, or by the reaction of a secondary antibody against immunoglobins of the host to the first antibody that is fluorescently labelled. In the latter case, the primary antibody is often conjugated to biotin and a fluorochrome-bound avidin acts as the secondary antibody. A more detailed technical overlook is provided by Peperzak et al. (2000).

Direct conjugates are useful when high concentrations of the target antigen are present or when cytometric multicolor analysis is planned with more than one antibody-dye-conjugate exhibiting different emission spectra. When high sensitivity is crucial, visualization by a secondary antibody is recommended because of higher fluorescence yield (Daley 1988): This happens because with direct conjugates only one antibody can react with the specific antigen site, whereas several secondary antibodies can react with the primary antibody. The detection signal is thereby increased manifold. Both approaches have been used in flow cytometry.

The commercially available antibody PCNA (anti-proliferating cell nuclear antigen-fluorescein,
Boehringer Mannheim, Germany) successfully enabled estimates of growth rates in cultures of Dunaliella tertiolecta (Lin et al., 1995) and field populations of the marine diatom Ethmodiscus rex (Lin and Carpenter, 1995). PCNA is an auxiliary protein of polymerase-delta and therefore essential for cellular DNA synthesis; synthesis and abundance of PCNA are cell-cycle-dependent, both increasing markedly during $\mathrm{S}$ phase (Lin et al., 1994), the cell cycle phase of DNA replication. The commercial antibody cross-reacted with several marine phytoplankton species (Skeletonema costatum, Thalassiosira weissflogii, Isochrysis galbana, Dunaliella tertiolecta; Lin et al., 1994). Although not yet applied to flow cytometry results from fluorescence microscopy have been promising.

Statin, a $57 \mathrm{kDa}$ nuclear protein, was recognized as a unique marker of quiescent cells, often also named $\mathrm{G}_{0}$ phase cells in the DNA cell cycle. Using flow cytometry, monoclonal antibodies against statin could discriminate resting $\left(\mathrm{G}_{0}\right)$ from potentially proliferating $\left(\mathrm{G}_{1}\right)$ human fibroblasts within a cell fraction having the same DNA content (Pellicciari et al., 1995). The expression of statin was inversely correlated with that of PCNA. Although not tested in non-mammalian cells, statin might prove useful to detect resting or dormant cells among morphologically identical phytoplankton, provided statin is as conservatively expressed among different types of organisms as PCNA (Lin et al., 1994) seems to be.

Cytometric immunofluorescent detection of monoclonal antibodies against thymine dimers, first developed for medical research (Roza et al., 1988), illustrated the dynamics of DNA damage in marine phytoplankton upon UV-B radiation (Buma et al., 1995). Thymine dimers are frequently built upon DNA lesions under UV radiation (Tyrrell 1986), blocking the action of DNA polymerase (Setlow et al., 1963) and preventing genome replication. The cyclobutane ring of the dimers is broken by a group of enzymes known as photolyases, and this repair mechanism is induced by light with wavelengths of 330 to $450 \mathrm{~nm}$ (Buma et al., 1995). Thymine dimerspecific fluorescence in the marine diatom Cyclotella sp. was linearly related to the UV-B dose and no difference was detected in the vulnerability to UVinduced DNA damage between $\mathrm{G}_{1}$-phase (non-replicating) and $\mathrm{G}_{2}$-phase (replicating) cells (Buma et al., 1995). The specific growth rates of Cyclotella sp. (Buma et al., 1997) and Emiliania huxleyi (Gieskes and Buma, 1997) were inversely correlated with 


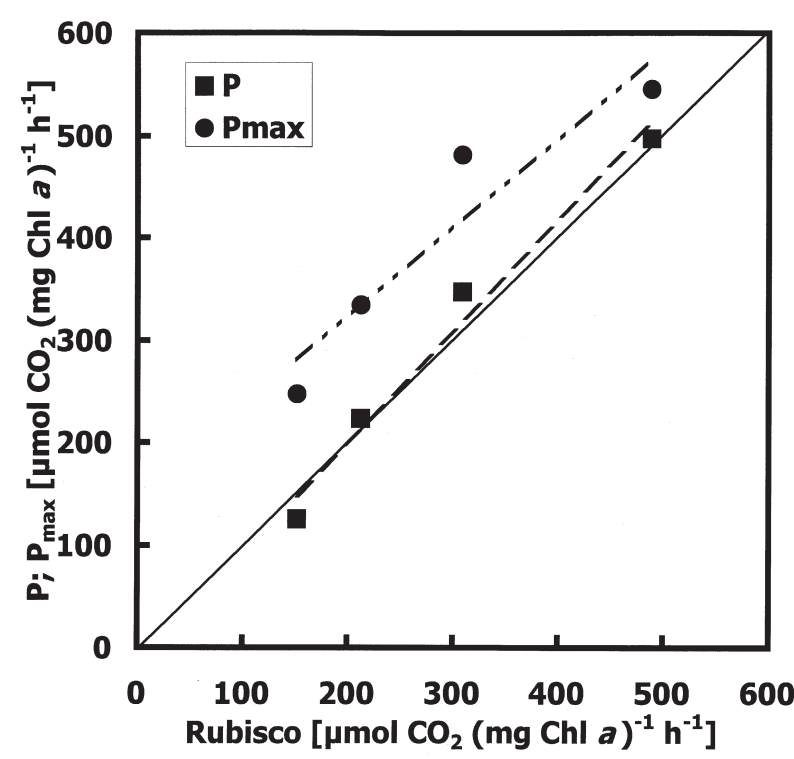

FIG. 2. - Relationship between ambient primary production $(\mathrm{P})$ and maximum primary production $(\mathrm{P})$ to maximum Rubisco activity

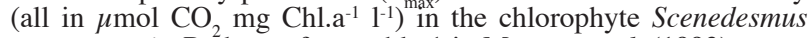
ecornis. Redrawn from table 1 in Mouget et al. (1993).

thymine dimer content in the cells. After UV-B exposure, thymine dimers were completely removed within 8-24 hrs under non-UV light (Buma et al., 1996; Gieskes and Buma, 1997).

The search for non-radioactive techniques to assess primary production resulted in the development of antibodies against ribulose-1,5-bisphosphate carboxylase (Rubisco; Orellana et al., 1988; Orellana and Perry, 1992). The cellular Rubisco concentration is directly related to the maximum rate of photosynthesis in higher plants and algae (Björkman, 1981; Rivkin, 1990; Orellana and Perry, 1992). From activity measurements of Rubisco, a linear relationship can be established to both actual and maximum photosynthesis as measured by ${ }^{14} \mathrm{CO}_{2}$-uptake (Fig. 2) although maximum Rubisco activity did not match maximum photosynthesis, and actual Rubisco activity was not related to photosynthesis at all (Mouget et al., 1993). The Rubisco antibodies raised from Chaetoceros gracilis protein (Orellana and Perry, 1992) cross-reacted with 26 species of phytoplankton and immunofluorescence could be detected by flow cytometry (Orellana and Perry, 1995). However, in a number of tested species, immunostaining was inconsistent and only $26-35 \%$ of cells from field samples were labelled in this study. Incomplete permeabilization of cell membranes - crucial to allow the relatively large antibody molecules to pass through several membranes into the chloroplast - was claimed to be responsible for the limited success of the applied probe. Ethanol proved to be the only suitable fixative for this labelling approach, which will limit its application to field studies because chlorophyll autofluorescence necessary to differentiate phytoplankton from other particles is bleached by the alcohol treatment. Glutaraldehyde fixation prevented cell labelling.

The uptake of nitrate by phytoplankton is a central issue in biological oceanography due to its importance to primary production and vertical flux of biogenic carbon. For an oceanic ecosystem, the rate of "new" production (relying on external inputs of nitrate in contrast to "regenerated" production thriving on ammonium; Dugdale and Goering, 1979) directly relates to the sinking flux of biogenic material (Eppley and Peterson, 1979). Assimilatory nitrate reductases catalyze the first step of nitrate assimilation, the reduction of $\mathrm{NO}_{3}$ to $\mathrm{NO}_{2}$. Despite growing knowledge of nitrate reductase (NR) activity in phytoplankton (Berges, 1997), important aspects of NR regulation and control at the cellular and molecular level have not been addressed adequately (Gao et al., 1993). Polyclonal antibodies against polypeptide sub-units provided cytometric detection and quantification of nitrate reductase in the marine diatom Skeletonema costatum (Jochem et al., 2000). The extremely low abundance of this protein of less than $10 \mathrm{fg} \mathrm{cell}^{-1}$ (Gao, 1997) demanded a secondary antibody approach for higher fluorescence yields. FITClabelled anti-rabbit antibodies from goat were employed to mark the rabbit-raised primary anti-NR. Chlorophyll extraction further enhanced sensitivity. The immunolabelling provided high resolution of NR synthesis induction in ammonium-grown $S$. costatum within the first $24 \mathrm{hrs}$ after inoculation into nitrate medium (Fig. 3a) and depicted the subsequent dynamics of this protein's abundance as the chemostat culture adapted to the change in nitrogen supply (Jochem et al., 2000). Cytometric anti-NR fluorescence was linearly related to cellular NR abundance derived from densiometry of Western Blots (Gao, 1997) but showed much higher resolution at low concentrations (Jochem et al., 2000; Fig. 3b). NR abundance as estimated by both flow cytometry and Western analyses of light-period samples exhibited a hyperbolic relationship to NR activity (Jochem et al., 2000), suggesting post-translational activation of the NR protein (Smith et al., 1992). Dark-period samples lacked any relationship between NR abundance and activity because NR activity is suppressed in the dark (Smith et al., 1992; Gao, 1997). 

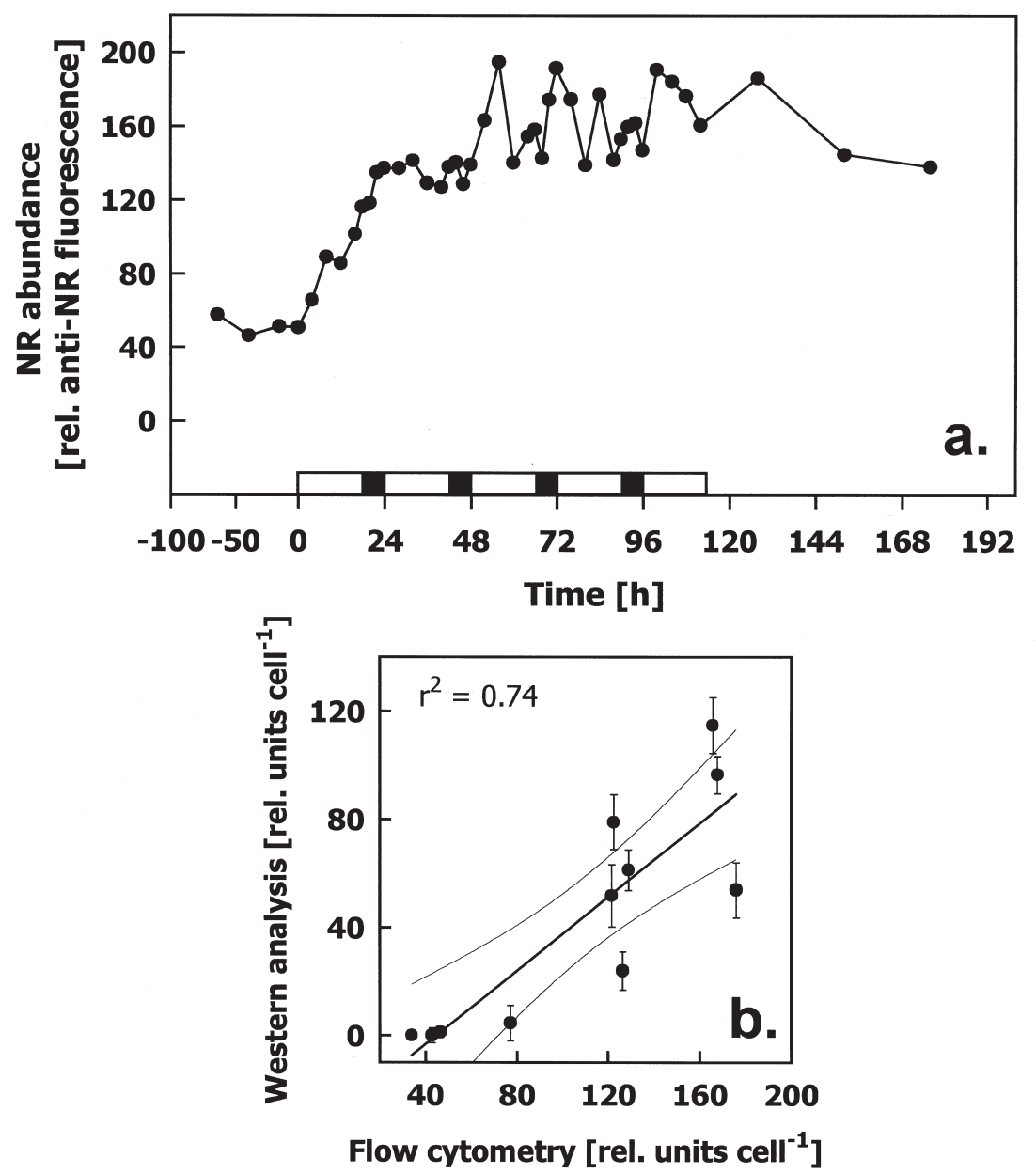

FIG. 3. - (a) Induction of nitrate reductase (NR; relative fluorescence units of anti-NR labelling) after a shift from ammonium to nitrate as nitrogen source $(\mathrm{t}=0)$ in the marine diatom Skeletonema costatum; light/dark cycle is indicated during the first 114 hrs after the nutrient shift when more than one daily sampling was performed. (b) Relationship between NR abundance as determined by densiometry of Western Blots and by immunolabelling and flow cytometry (both relative units) for mid-light period samples $\left(\mathrm{r}^{2}=0.74, p<0.001\right)$. From Jochem et $a l$., 2000.

The stickiness of diatom cells was assessed cytometrically by FITC-tagged concanavalin A, a lectin that binds to glucose and mannose on the cell surface (Waite et al., 1995). The stickiness, defined as the probability that two colliding diatoms will remain attached, is one of the most important factors regulating aggregate formation (Dam and Drapeau, 1995). By altering the biomass size spectrum, aggregates in turn can influence the vertical flux of biogenic carbon (Smetacek, 1985; Villareal et al., 1993) and change the availability of food to grazers (Stoecker et al., 1981). Stickiness is believed to arise from the exudation of mucus, either present on the cell surface (Smetacek, 1985) or as transparent exopolymer particles (TEP) in seawater (Passow et al., 1994; Dam and Drapeau, 1995). Concanavalin A fluorescence varied 5-fold among different diatom species and 2-3-fold within a given species in dif- ferent physiological states (Waite et al., 1995); for Thalassiosira pseudonana and Chaetoceros neogracile, cell surface sugar compounds increased with nitrate and silicate limitation in batch cultures. Although the concanavalin-A-FITC approach was applicable to formalin-fixed cells as well, half saturation time of the staining was longer ( $4.1 \mathrm{hrs}$ vs. 0.2 hrs) and final fluorescence yield higher (0.05 vs. 0.03 ) in preserved as compared to live cells.

\section{MOLECULAR PROBES FOR METABOLIC ACTIVITY AND NUTRIENT STATUS: KINETIC MEASUREMENTS}

The principle of kinetic measurements is the application of non-fluorescent substrates that are processed by metabolic processes of interest with- 
in the cells, cleaving the applied molecule and releasing a strong fluorigen that has to exhibit low leakage from the cells. Hydrophilic dyes such as fluorescein or FITC have proved useful but others are in use as well.

The cleavage of the non-fluorescent substrate results in an accumulation of fluorescence within the cell that initially increases until saturation. In contrast to fluorescence microscopy, flow cytometry cannot only distinguish labelled from non-labelled cells, but can estimate the fraction of the population with a positive reaction on the applied substrate. It can also provide a quantitative measure, in terms of relative fluorescence, of the rate at which the cells process the substrate. Quantitative measurements must, therefore, be taken either after saturation of fluorescence accumulation or at a specific timepoint after substrate addition that is standardized for all samples to be compared.

Fluorescein diacetate, originally introduced to differentiate metabolically active from inactive bacteria in soils (Schnürer and Roswall, 1982), water (Holzapfel-Pschorn et al., 1987) and marine sediments (Köster et al., 1991; Gumprecht et al., 1995), was shown to be applicable to the study of phytoplankton physiology as well. FDA is a nonpolar, nonfluorescent substance, which enters the cells freely. Inside the cell, nonspecific esterases, among them lipase and acylase but not acetylcholinesterase (Guilbaut and Kramer, 1966), break the FDA molecule into one brightly fluorescing fluorescein and two acetate molecules. Being highly polar, the fluorescein is trapped within cells exhibiting cell membrane integrity and the amount of fluorescence therefore increases over time depending on the metabolic activity of the esterases. The FDA enzyme assay has recently been complemented with a protocol for cryopreservation of labelled phytoplankton (Faber et al., 1997) that will greatly improve the processing of large sample sets and the application in field studies.

The esterases involved in the FDA assay turn over on a time frame of several hours (Yentsch et al., 1988). Therefore, this technique seems appropriate to detect changes in metabolic activity on a day-today or even shorter basis, which makes it well suited to monitor short-term phytoplankton responses to environmental changes and pollution. Reduced esterase activity in terms of FDA fluorescence accumulation in Selenastrum capricornutum was documented after exposure to high (450 ppb) concentrations of copper, whereas lower concentrations induced an increase in esterase activity; $27 \mathrm{hrs}$ into the incubation, esterases resumed their initial performance irrespective of $\mathrm{Cu}$ concentrations (Arsenault et al., 1993). Using flow cytometry, Geary et al. (1998) distinguished between cyanobacteria, Microcystis aeruginosa, grown under different light intensities or under phosphate replete/deplete conditions for 2 days; the light-covarying FDA fluorescence corresponded to different growth rates. Covariation of FDA fluorescence and maximum photosynthetic carbon fixation with cell volume was reported from 8 phytoplankton species ranging about 2 to $15 \mu \mathrm{m}$ in size (Dorsey et al., 1989). The regulation of metabolic activity in phytoplankton upon prolonged darkness was also assessed by FDA (Dorsey et al., 1989; Jochem, 1999). The latter study revealed two distinct survival strategies among phytoflagellates (Fig. 4): One group of species adjusted to darkness by reducing their metabolic activity within a few days; they were able to sustain their population abundance and resume rapid
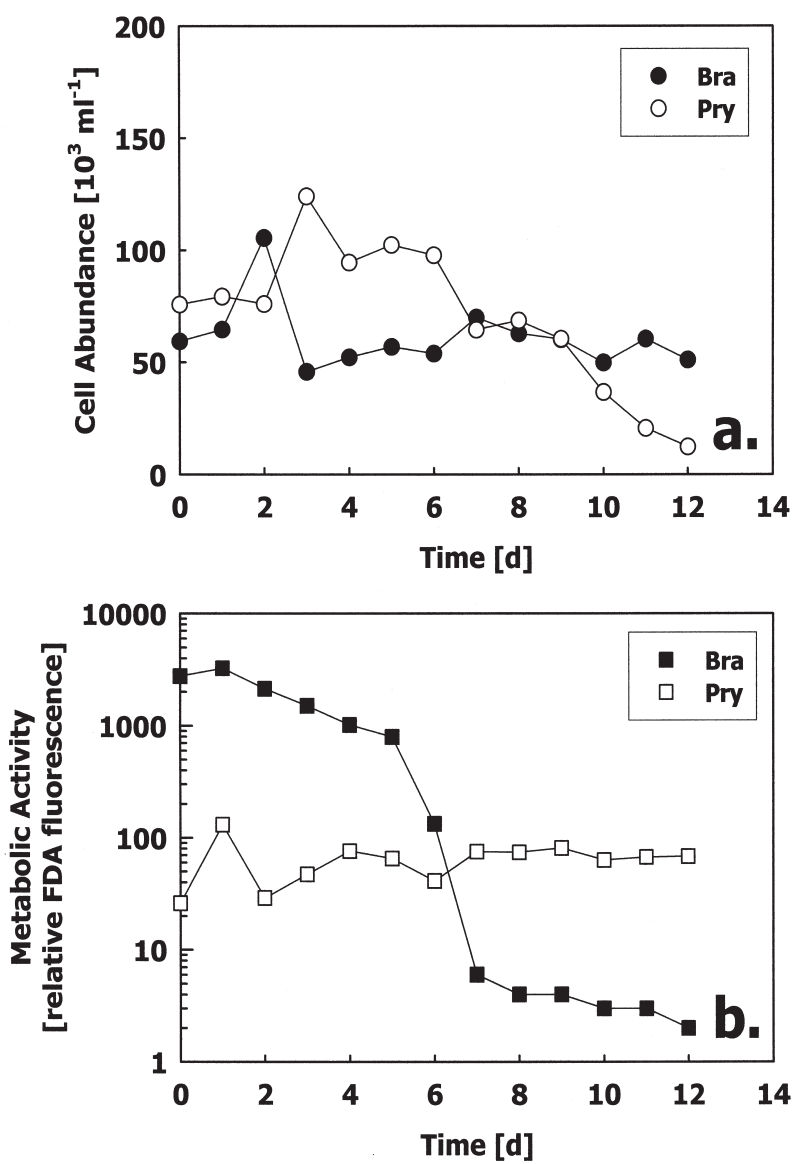

FIG. 4. - Dark survival strategies in two phytoflagellates. (a) Cell abundance $\left(10^{3} \mathrm{ml}^{-1}\right)$, (b) cellular metabolic activity in terms of mean FDA fluorescence (rel. units). Bra = Brachiomonas submarina Pry = Prymnesium parvum. After Jochem, 1999. 
growth after re-illumination. The other group exhibited no change in metabolic activity upon darkness and seemed to run out of energy; these species could not sustain their cell numbers in the dark and did not resume growth after re-illumination.

Changes in peroxidase activity in the marine diatom Phaeodactylum tricornutum exposed to copper pollution were monitored by dihydroethidium, also called hydroethidine (Cid et al., 1996a). The oxidation of the initially blue fluorescent dye by peroxidase in the presence of reactive oxygen species (peroxide or superoxide) within the cell results in a brightly red fluorescent ethidium. In the presence of chlorophyll autofluorescence, the authors monitored the red peroxidase activity fluorescence in the FL2 channel (560-590 nm) of a Becton-Dickinson FACScan after $30 \mathrm{~min}$ incubation with the dye. Cytometric analysis revealed an increase in peroxidase activity after 48 hrs and a subsequent decrease to initial levels after $96 \mathrm{hrs}$ of copper exposure.

A new family of fluorogen-bound enzyme substrates called ELF-97 ${ }^{\text {тM }}$ (Enzyme Labelled Fluorescence; Molecular Probes, Eugene, OR) provides a powerful tool for individual phytoplankton analysis in complex field assemblages (Larison et al., 1995; Haugland, 1996). The ELF substrate is soluble and low fluorescent. Hydrolysis of the substrate results in the precipitation of an insoluble fluorescent product with excitation maximum at $365 \mathrm{~nm}$ and green fluorescence emission $(515 \mathrm{~nm}$; Haugland, 1996).

ELF alkaline phosphatase substrate (Molecular Probes, Eugene, OR) proved useful in the study of the physiological status of phosphorous nutrition in phytoplankton (González-Gil et al., 1998; Dyhrman and Palenik, 1999). Phosphate-limited cells could be clearly distinguished from unlimited cells in culture and field samples, and alkaline phosphatase activity could be cytometrically quantified in dependence of phosphate concentration in algal cultures (González-Gil et al., 1998). Cells were incubated in a commercially available ELF buffer for 30 mins at room temperature in the dark and then washed in 10 $\mathrm{mM}$ phosphate saline buffer (PBS); thus treated preparations kept their ELF fluorescence over 3 months dark storage at $4{ }^{\circ} \mathrm{C}$ (González-Gil et al., 1998). ELF represents an "off-the-shelf" probe of $P$ starvation that provides the same information that can be obtained by molecular probes or antibodies for cell-surface proteins involved in P-uptake (Dyhrman and Palenik, 1995). In contrast to antibodies with mostly specific cross-reactivity with only one or a group of some closely related species, ELF is applicable to a wide variety of species (González-Gil et al., 1998) though potentially not for all; namely diatoms were scarcely labelled in field samples in which dinoflagellates showed bright labeling (Dyhrmann and Palenik, 1999).

Higher ELF fluorescence per cell in Isochrysis galbana as compared to the much larger Amphidinium sp. could not be related to alkaline phosphatase activity as revealed by other methods (González-Gil et al., 1998). The authors conclude that higher fluorescence in I. galbana was due to higher affinity of its phosphatase for ELF. Thorough intercalibration is still required for quantitative comparison of phosphatase activity in different species using ELF.

The manufacturer states that ELF fluorescence is detectable by $488 \mathrm{~nm}$ blue light excitation used in benchtop cytometers (Haugland, 1996), which was confirmed by Pecorino et al. (1996). However, Dyhrman and Palenik (1999) were not able to track ELF fluorescence using $488 \mathrm{~nm}$ excitation but were successful with $363 \mathrm{~nm}$ excitation. Cytometric detection of ELF in phytoplankton was performed by UV excitation as well (FACS Vantage, 100 mW Innova laser, 333-364 nm; González-Gil et al., 1998). The positive results under blue light excitation (Pecorino et al., 1996) might be related to the lack of autofluorescence in the studied cells. So far it seems that ELF-97 ${ }^{\mathrm{TM}}$ substrates, which include probes for lipase, sulfatase, esterase and others (Haugland, 1996), might remain restricted to more expensive and powerful machines carrying a UV laser.

\section{OUTLOOK}

Development of molecular probes for a variety of ecologically significant physiological processes have progressed well over the last few years. Today, molecular probes to detect nitrogenase activity, iron limitation, copper pollution, and phosphate stress or to discriminate between active and inactive cells are already tested in field samples.

To raise antibodies in mammalian hosts, the antigen of interest should be of a proteinaceous nature, either a structural protein of the cell or an enzyme. In cases where the target of interest is a non-protein, it can be bound to carrier proteins. For example, by binding to bovine serum albumin (BSA), antibodies against brevetoxin, the toxic multi-ring polyether produced by the harmful 
dinoflagellate Ptychodiscus brevis (Baden et al., 1984, 1988), and tetrahydropurine-based dinoflagellate toxins causing paralytic shellfish poisoning (Guire et al., 1988) were raised. Antibodies against the amnesic shellfish poisoning toxin domoic acid were produced by ovalbumin binding (Smith and Kitts, 1995). None of those antibodies has been applied to flow cytometry yet but potentially provide tools to assess the cellular toxin concentration in dinoflagellates and its variation with environmental factors. This is especially promising where toxic species can be marked by taxon-specific antibodies (Peperzak et al., 2000).

Specific cell surface proteins expressed upon phosphate depletion have been identified in the chlorophyte Dunaliella tertiolecta (Graziano et al., 1995) and Synechococcus sp. (Scanlan et al., 1997). Antibodies raised against the latter also cross-reacted with Prochlorococcus sp. and potentially such antibodies might prove useful in detecting phosphate stress by flow cytometry in mixed populations. The expression of flavodoxin instead of ferredoxin, detected by specific polyclonal antibodies, was shown to reveal iron limitation in marine phytoplankton (LaRoche et al., 1995, 1996). And ntcA, a transcriptional activator that regulates the transcription of a series of genes encoding proteins for nitrate uptake and assimilation in Synechococcus sp., has recently been isolated and sequenced (Lindell et al., 1998); ntcA was suppressed by ammonium, whereas it was supported by nitrate as nitrogen source and it might eventually provide a tool to detect nitrate versus ammonium as principle nitrogen source of phytoplankton growth.

Further biomarkers for ecologically and environmentally significant processes in marine organisms are to be developed and tested in laboratory and field studies. Fluorescent dyes for cell constituents (static measurements I), commonly used in histochemistry, are hitherto largely underused in aquatic research and flow cytometry. Only the different dyes for DNA labelling gained much interest by researchers using aquatic cytometry. Otherwise, cytometric application of such dyes is still restricted to limited and isolated laboratory studies. It can be assumed, however, that this group of dyes can provide a much wider, yet unexploited palette of applications, which can demonstrate changes in cellular components upon environmental changes and differences in responses among different species. Such results will enhance our understanding on how biodiversity is sustained and phytoplankton flourishes in oceans and lakes on a cellular level. The ease of use of such dyes as compared to more complex preparations involved in immunolabelling (Peperzak et al., 2000) makes further development and investigation of fluorescent static measurements desirable.

Much more effort was directed towards the development of molecular probes during the last decade. However, a lot of these applications still rely on gels and blots. Although each development of molecular tools starts from gels and blots, these techniques are hardly quantitative and too laborious for routine sample monitoring. Transferring these molecular tools to rapid and easy to use techniques for routine application in environmental monitoring and ecosystem studies will provide a valuable step for research in the new century. Such techniques may include immobilized antibodies or other biomolecules on the surface of optical filters, fibers or other surfaces suitable for later optical detection, and flow cytometry.

A major problem of present molecular probes is their specificity. Although highly specific antibodies are sometimes desired, there is a vast field of applications and scientific questions that would prefer a more universal probe. Nitrate reductase antibodies, for example, may prove useful to investigate phytoplankton nitrogen dynamics, a key question in biological oceanography. The hitherto applied antibodies cross-react, however, only with dinoflagellates (Fritz et al. 1996) or centric diatoms (Gao, 1997; Jochem et al., 2000). Antigenecity of NR from different phytoplankton species seems divergent (Gao et al., 1993), and despite homologous amino acid sequences corresponding to redox centers the overall similarity in amino acid sequences from different plant and fungal NR is less than 50\% (Campbell and Kinghorn 1990). The generation of immunoprobes against widely conserved peptide sequence domains offers one approach for generic immunoassays. However, the observation that antibodies targeting single epitopes may not yield sufficient signal for detection of low abundant targets, such as NR (Jochem et al., 2000), requires further development of high fluorescence yield fluorochromes such as the Alexa ${ }^{\circledR}$ series (Haugland, 1996).

Whereas, for example, the ELFTM substrates for alkaline phosphatase are already commercially available and ready for use in routine applications, most of the other molecular probes are still in the development and testing phase in separate research laboratories. It can be assumed that the development of new probes and techniques will remain a primary 
responsibility of research laboratories. A fast and efficient technology transfer for commercial production and distribution is necessary, however, to provide new probes and technologies in sufficient quantity to allow for a wide and routine application in aquatic ecology, so that their promises can be exploited efficiently and broadly. Since numerous probes may be directed towards environmental monitoring and water quality control and may open a wide market, given the ease and time-saving of cytometric analyses, commercial participation in probe development should be encouraged for rapid production and distribution of such new probes.

Since the environment directly affects cells, not populations, the measurement of individual cells is desirable. In addition to differences among separate species in physiological capacities such as, for example, photosynthetic efficiency, microenvironments such as nutrient patches and biological factors such as cell cycle stage might cause non-uniform distributions of properties among the cells of a single species population (Olson and Zettler, 1995). Cytometric analysis of variable chlorophyll fluorescence (Olson and Zettler, 1995; Olson et al. 1996, 1999), therefore, most valuably complements bulk measurements by fluorometer-based pump-andprobe systems. This technique provides a powerful tool to assess the regulation of phytoplankton growth and to estimate the contributions of different phytoplankton groups to total primary productivity (Olson et al., 1999). But today only one self-modified instrument is set up to provide such measurements. For wide application in ecological research, the necessary technical modifications to commercial flow cytometers should be commercially available as well. Since such applications are off the main stream of major commercial manufacturers, which primarily direct their developments to medical research and diagnostic, small business solutions might provide better support for the special needs of oceanography. Again, fast and efficient technology transfer from academically based research and development to such small businesses should be encouraged.

Over all, recent developments in cytometry instrumentation and phytoplankton probes have provided tools for much deeper insights into processes that govern plankton development in response to environmental conditions on a single-cell basis. More progress is steadily achieved, and probing the physiological state at the single-cell level by flow cytometry seems still in its infancy.

\section{ACKNOWLEDGEMENTS}

The Nancy Lee and Perry Bass Endowment to the University of Texas at Austin Marine Science Institute supported preparation of this manuscript.

\section{REFERENCES}

Abalde, J., A. Cid, S. Reiriz, E. Torres and C. Herrero. - 1995. Response of the marine microalga Dunaliella tertiolecta (Chlorophyceae) to copper toxicity in short time experiments. Bull. Environ. Contam. Toxicol. 54: 317-324.

Ackelson, S.G., R.W. Spinrad, C.M. Yentsch, J. Brown and W. Korjeff-Bellows. - 1988. Phytoplankton optical properties: flow cytometric examination of dilution-induced effects. Appl. Optics 27: 1262-1269.

Arsenault, G., A.D. Cvetkovic and R. Popovic. - 1993. Toxic effects of copper on Selenastrum capricornutum measured by a flow cytometry-based method. Water Pollut. Res. J. Can. 28: 757-765.

Baden, D.G., T.J. Mende and A.M. Szmant. - 1988. Brevetoxins and binding: sodium channels versus antibodies. In: Yentsch, C.M., F.C. Mague and P.K. Horan (eds.), Immunochemical approaches to coastal, estuarine and oceanographic questions, pp. 134-144. Lecture Notes on Coastal and Estuarine Studies, Springer, New York.

Baden, D.G., T.J. Mende, J. Walling and D.R. Schultz. - 1984. Specific antibodies directed against toxins of Ptychodiscus brevis. Toxicon 22: 783-789.

Berges, J.A. - 1997. Algal nitrate reductases. Eur. J. Phycol. 32: 3-8.

Björkman, O. - 1981. Responses to different quantum flux densities. In: Lange, O.L., P.S. Nobel, C.B. Osmund and H. Ziegler (eds), Encyclopedia of Plant Physiology, pp. 57-107. New Series vol. 12a. Springer, Berlin.

Buma, A.G.J., A.H. Engelen and W.W.C. Gieskes. - 1997. Wavelength-dependent induction of thymine dimers and growth rate reduction in the marine diatom Cyclotella sp. exposed to ultraviolet radiation. Mar. Ecol. Prog. Ser. 153: 91-97.

Buma, A.G.J., E.J. van Hannen, L. Roza, M.J.W. Veldhuis and W.W.C. Gieskes. - 1995. Monitoring ultraviolet-B-induced DNA damage in individual diatom cells by immunofluorescent thymine dimer detection. J. Phycol. 31: 314-321.

Buma, A.G.J., E.J. van Hannen, M.J.W. Veldhuis and W.W.C. Gieskes. - 1996. UV-B induces DNA damage and DNA synthesis delay in the marine diatom Cyclotella sp. Sci. Mar. 60(Suppl. 1): 101-106.

Campbell, W.H. and J.R. Kinghorn. - 1990. Functional domains of assimilatory nitrate reductases and nitrite reductases. Trends Biochem. Sci. 15: 315-319.

Cid, A., P. Fidalgo, C. Herrero and J. Abalde. - 1995. Flow cytometry of acute physiological changes in a marine diatom stressed by copper. Microbiologia Sem. 11: 455-460.

Cid, A., P. Fidalgo, C. Herrero and J. Abalde. - 1996a. Toxic action of copper on the membrane system of a marine diatom measured by flow cytometry. Cytometry 25: 32-36

Cid, A., C. Herrero and J.E. Abalde. - 1996b. Functional analysis of phytoplankton by flow cytometry: A study of the effect of copper on a marine diatom. Sci. Mar. 60(Suppl. 1): 303-308.

Cid, A., E. Torres, C. Herrero and J.E. Abalde. - 1997. Disorders provoked by copper in the marine diatom Phaeodactylum tricornutum in short-time exposure assays. Cah. Biol. Mar. 38: 201-206

Cunningham, A. and G.A. Buonaccorsi. - 1992. Narrow angle forward light scattering from individual algal cells: implications for size and shape discrimination in flow cytometry. J. Plankton Res. 14: 223-234.

Daley, J.F. - 1988. Immunofluorescent reagents: Preparation and analysis. In: Yentsch, C.M., F.C. Mague and P.K. Horan (eds.), Immunochemical approaches to coastal, estuarine and oceanographic questions. Lecture Notes on Coastal and Estuarine Studies, Springer, New York.

Dam, H.G. and D.T. Drapeau. - 1995. Coagulation efficiency, organic matter glues and the dynamics of particles during a 
phytoplankton bloom in a mesocosm study. Deep-Sea Res. 42: 111-123.

Detmer, A.E., V. Trenkel, H.C. Giesenhagen, H. Auf dem Venne and F.J. Jochem. - 1993. Phototrophic and heterotrophic picoand nanoplankton in anoxic waters of the Central Baltic Sea. Mar. Ecol. Prog. Ser. 99: 197-203.

Dorsey J., C.M. Yentsch, S. Mayo and C. McKenna. - 1989. Rapid analytical technique for the assessment of cell metabolic activity in marine microalgae. Cytometry 10: 622-628.

Dubelaar, G.B.J., J.W.M. Visser and M. Donze. - 1987. Anomalous behaviour of forward and perpendicular light scattering of cyanobacterium owing to intracellular gas vacuoles. Cytometry 8: $539-544$.

Dugdale, R.C. and J.J. Goering. - 1979. Uptake of new and regenerated forms of nitrogen in primary productivity. Limnol. Oceanogr. 12: 196-206.

Dyhrman, S. and B. Palenik. - 1995. Identification and characterization of a Prorocentrum minimum cell surface protein specifically induced under phosphorus limitation. J. Phycol. 31: 6.

Dyhrman, S. and B. Palenik. - 1999. Phosphorus stress detected in cultures and field populations of the dinoflagellate Prorocentrum minimum using a single cell alkaline phosphatase assay. Appl. Environ. Microbiol. 65: 3205-3212.

Eppley, R.W. and B.J. Peterson. - 1979. Particulate organic matter flux and planktonic new production in the deep ocean. Nature 28: 677-680.

Faber, M.J., L.M.J. Smith, H.J. Boermans, G.R. Stephenson, D.G. Thompson and K.R. Solomon. - 1997. Cryopreservation of fluorescent marker-labelled algae (Selenastrum capricornutum) for toxicity testing using flow cytometry. Environ. Toxicol. Chem. 16: 1059-1067.

Falkowski, P.G., R.M. Greene and R.J. Geider. - 1992. Physiological limitations on phytoplankton productivity in the ocean. Oceanogr. 5: 84-91.

Falkowski, P.G., D. Ziemann, Z.S. Kolber and P.K. Bienfang. 1991. Role of eddy pumping in enhancing primary production in the ocean. Nature 352: 55-58.

Fritz, L., C.G. Stringher and P. Colepicolo. - 1996. Immunolocalization of nitrate reductase in the marine dinoflagellate Gonyaulax polyedra (Pyrrophyta). J. Phycol. 32: 5823-5827.

Fritz, L. and R.E. Triemer. - 1985. A rapid simple technique utilizing Calcofluor white M2R for the visualization of dinoflagellate thecal plates. J. Phycol. 21: 662-664.

Furuya, K. and W.K.W. Li. - 1992. Evaluation of photosynthetic capacity in phytoplankton by flow cytometric analysis of DCMU-enhanced chlorophyll fluorescence. Mar. Ecol. Prog. Ser. 88: 279-287.

Gao, Y. - 1997. Nitrate assimilation in the marine diatom Skeletonema costatum (Bacillariophyceae): Biochemical and environmental regulation. Ph.D. thesis, University of Southern California, Los Angeles. $211 \mathrm{pp}$.

Gao, Y., G.J. Smith and R.S. Alberte. - 1993. Nitrate reductase from the marine diatom Skeletonema costatum. Plant Physiol. 103: $1437-1445$.

Geary S., G. Ganf and J. Brookes. - 1998. The use of FDA and flow cytometry to measure the metabolic activity of the cyanobacteria, Microcystis aeruginosa. Verh. Internat. Verein Limnol. 26: 2367-2369.

Geider, R.J., R.M. Greene, Z. Kolber, H.L. MacIntyre and P.G. Falkowski. - 1993. Fluorescence assessment of the maximum quantum efficiency of photosynthesis in the western North Atlantic. Deep-Sea Res. 40: 1205-1224.

Gieskes, W.W.C. and A.G.J. Buma. - 1997. UV damage to plant life in a photobiologically dynamic environment: The case of marine phytoplankton. Plant Ecology 128: 16-25.

González-Gil, S., B.A. Keafer, R.V.M. Jovine, A. Aguilera, S. Lu and D.M. Anderson. - 1998. Detection and quantification of alkaline phosphatase in single cells of phosphorus-starved marine phytoplankton. Mar. Ecol. Prog. Ser. 164: 21-35.

Graziano, L.M., R.J. Geider and J. LaRoche. - 1995. Physiological responses of $D$. tertiolecta to phosphorus limitation. J. Phycol. 31 Suppl. 3: 22

Graziano, L.M., R.J. Geider, W.K.W. Li and M. Olaizola. - 1996. Nitrogen limitation of North Atlantic phytoplankton: Analysis of physiological condition in nutrient enrichment experiments. Aquat. Microb. Ecol. 11: 53-64.

Guilbaut G.G. and D.N. Kramer. - 1966. Lipolysis of fluorescein and eosin esters - kinetics of hydrolysis. Analyt. Biochem. 14: 28-40.
Guire, P.E., P.H. Duquette, R.A. Amos, J.C. Behrens, M.W. Josephson and R.P. Chambers. - 1988. Preparation of model haptens to express common epitopes of PSP toxins. In: Yentsch, C.M., F.C. Mague and P.K. Horan (eds.), Immunochemical approaches to coastal, estuarine and oceanographic questions, pp. 145-154. Lecture Notes on Coastal and Estuarine Studies, Springer, New York.

Gumprecht R., H. Gerlach and A. Nehrkorn. - 1995. FDA hydrolysis and resazurin reduction as a measure of microbial activity in sediments from the south-east Atlantic. Helgoländer Meeresunters. 49: 189-199.

Haugland, R.P. - 1996. Handbook of fluorescent probes and research chemicals. $6^{\text {th }}$ ed. Molecular Probes, Eugene, OR. 680 pp.

Hobbie, J.E., R.J. Daley and S. Jasper. - 1977. Use of nuclepore filters for counting bacteria by fluorescence microscopy. Appl. Environ. Microbiol. 33: 1225-1228.

Holzapfel-Pschorn, A., U. Obst and K. Haberer. - 1987. Sensitive methods for the determination of microbial activities in water samples using fluorigenic substrates. Fresenius Z. Analyt. Chem. 327: 521-523.

Jensen, M.O. and O. Moestrup. - 1997. Autecology of the toxic dinoflagellate Alexandrium ostenfeldii: Life history and growth at different temperatures and salinities. Eur. J. Phycol. 32: 9-18.

Jochem, F.J. - 1988. On the distribution and importance of picocyanobacteria in a boreal inshore area (Kiel Bight, Western Baltic). J. Plankton Res. 10: 1009-1026.

Jochem, F.J. - 1989. Distribution and importance of autotrophic ultraplankton in a boreal inshore area (Kiel Bight, Western Baltic). Mar. Ecol. Prog. Ser. 53: 153-168.

Jochem, F.J. - 1999. Dark survival strategies in marine phytoplankton assessed by cytometric measurement of metabolic activity with fluorescein diacetate. Mar. Biol. 135: 721-728.

Jochem, F.J. and D. Meyerdierks. - 1999. Cytometric measurement of the DNA cell cycle in the presence of chlorophyll autofluorescence in marine eukaryotic phytoplankton by the blue-light excited dye YoYo-1. Mar. Ecol. Prog. Ser. 185: 301-307.

Jochem, F.J., G.J. Smith, Y. Gao, R.C. Zimmerman, D. Robertson, A. Cabello-Pasini, D.G. Kohrs and R.S. Alberte. - 2000. Cytometric quantification of nitrate reductase by immunolabeling of polyclonal antibodies in the marine diatom Skeletonema costatum. Cytometry 39, 173-178.

Kolber, Z.S., R.T. Barber, K.H. Coale, S.E. Fitzwater, R.M. Greene, K.S. Johnson, S. Lindley and P.G. Falkowski. - 1994. Iron limitation of phytoplankton photosynthesis in the equatorial Pacific Ocean. Nature 371: 145-149.

Kolber, Z.S. and P.G. Falkowski. - 1993. Use of active fluorescence to estimate phytoplankton photosynthesis in situ. Limnol. Oceanogr. 38: 1646-1665.

Kolber, Z.S., K. Wyman and P.G. Falkowski. - 1990. Natural variability in photosynthetic energy conversion efficiency: a field study in the Gulf of Maine. Limnol. Oceanogr. 35: 72-79.

Köster, M., P. Jensen and L.A. Meyer-Reil. - 1991. Hydrolytic activities of organisms and biogenic structures in deep-sea sediments. In: Chrost, R.J. (ed), Microbial enzymes in aquatic environments, pp. 298-310. Springer, New York.

Larison, K.D., R. BreMiller, K.W. Wells, I. Clements and R.P. Haugland. - 1995. Use of a new fluorigenic phosphatase substrate in immunohistochemical applications. J. Histochem. Cytochem. 43: 77-83.

LaRoche, J., P.W. Boyd, R.M.L. McKay and R. J. Geider. - 1996. Flavodoxin as an in situ marker for iron stress in phytoplankton. Nature 382: 802-805.

LaRoche, J., H. Murray, M.V. Orellana and J. Newton. - 1995. Flavodoxin expression as an indicator of iron limitation in marine diatoms. J. Phycol. 31: 520-530.

Li, W.K.W., T. Zohary, Y.Z. Yacobi and A.M. Wood. - 1993 Ultraphytoplankton in the eastern Mediterranean Sea: Towards deriving phytoplankton biomass from flow cytometric measurements of abundance, fluorescence and light scatter. Mar. Ecol. Progr. Ser. 102: 79-87.

Lin, S. and E.J. Carpenter. - 1995. Growth characteristics of marine phytoplankton determined by cell cycle proteins: The cell cycle of Ethmodiscus rex (Bacillariophyceae) in the southwestern North Atlantic Ocean and Caribbean Sea. J. Phycol. 31: 778-785.

Lin, S., J. Chang and E.J. Carpenter. - 1994. Detection of proliferating cell nuclear antigen analog in four species of marine phytoplankton. J. Phycol. 30: 449-456. 
Lin, S., J. Chang and E.J. Carpenter. - 1995. Growth characteristics of phytoplankton determined by cell cycle proteins: PCNA immunostaining of Dunaliella tertiolecta (Chlorophyceae). J. Phycol. 31: 388-395.

Lindell, D., E. Padan and A.F. Post. - 1998. Regulation of ntcA expression and nitrite uptake in the marine Synechococcus sp. strain WH 7803. J. Bacteriol. 180: 1878-1886

Martin, J.H. and S. E. Fitzwater. - 1988. Iron deficiency limits phytoplankton growth in the north-east Pacific Subarctic. Nature 331: 341-343.

Martin, J.H., R.M. Gordon and S.E. Fitzwater. - 1990. Iron in Antarctic waters. Nature 345: 156-158.

Mouget, J.L., R.C. Beeson jr., L. Legendre and J. de la Noüe. - 1993. Inadequacy of Rubisco initial and total activities to account for observed rates of photosynthetic carbon dioxide assimilation by Scenedesmus ecornis. Eur. J. Phycol. 28: 99-106.

Murphy A.M. and T.J. Cowles. - 1997. Effects of darkness on multi-excitation in vivo fluorescence and survival in a marine diatom. Limnol. Oceanogr. 42: 1444-1453.

Olson, R.J., A.M. Chekalyuk and H.M. Sosik. - 1996. Phytoplankton photosynthetic characteristics from fluorescence induction assays of individual cells. Limnol Oceanogr. 41: 1253-1263.

Olson, R.J., H.M. Sosik and A.M. Chekalyuk. - 1999. Photosynthetic characteristics of marine phytoplankton from pumpduring-probe fluorometry of individual cells at sea. Cytometry 37: 1-13.

Olson, R.J. and E.R. Zettler. - 1995. Potential of flow cytometry for "pump and probe" fluorescence measurements of phytoplankton photosynthetic characteristics. Limnol. Oceanogr. 40: 816-820.

Orellana, M.V. and M.J. Perry. - 1992. An immunoprobe to measure Rubisco concentrations and maximal photosynthetic rates in individual phytoplankton cells. Limnol. Oceanogr. 37: 478-490.

Orellana, M.V. and M.J. Perry. - 1995. Optimization of an immunofluorescent assay of the internal enzyme ribulose-1,5-bisphosphate carboxylase (Rubisco) in single phytoplankton cells. J. Phycol. 31: 785-794.

Orellana, M.V., M.J. Perry and B.A. Watson. - 1988. Probes for assessing single-cell primary production: Antibodies against ribulose-1,5-bisphosphate carboxylase (RuBPCASE) and peridinin/chlorophyll a protein (PCP). In: Yentsch, C.M., F.C. Mague and P.K. Horan (eds.), Immunochemical approaches to coastal, estuarine and oceanographic questions, pp. 243-262. Lecture Notes on Coastal and Estuarine Studies, Springer, New York.

Overnell, J. - 1975. The effect of heavy metals on photosynthesis and loss of cell potassium in two species of marine alga, Dunaliella tertiolecta and Phaeodactylum tricornutum. Mar. Biol. 29: 99-103.

Passow, U., A.L. Aldredge and B.E. Logan. - 1994. The role of particulate carbohydrate exudates in the flocculation of diatom blooms. Deep-Sea Res. 41: 335-357.

Pecorino, L.T., P. Brockes and A. Entwistle. - 1996. Semi-automated position analysis using laser scanning microscopy of cells transfected in a regenerating Newt limb. J. Histochem. Cytochem. 44: 559-569.

Pellicciari, C., R. Mangiarotti, M.G. Bottone, M. Danova and E. Wang. - 1995. Identification of resting cells by dual-parameter flow cytometry of statin expression and DNA content. Cytometry 21: 329-337.

Peperzak, L., E.G. Vrieling, B. Sandee and T. Rutten. - 2000. Immuno flow cytometry in marine phytoplankton research. Sci. Mar. 64(2): 165-181.

Rivkin, R.B. - 1990. Photoadaptation in marine phytoplankton: variations in ribulose-1,5-bisphosphate activity. Mar. Ecol. Prog. Ser. 62: 61-72.

Roza, L., K.J.M. van der Wulp, S.J. MacFarlane, P.H.M. Lohman and R.A. Braan. - 1988. Detection of cyclobutane thymine dimers in DNA of human cells with monoclonal antibodies raised against a thymine dimer-containing tetranucleotide. Photochem. Photobiol. 48: 627-633.

Samson, G., J.C. Morissette and R. Popovic. - 1988. Copper quenching of the variable fluorescence in Dunaliella tertiolecta. New evidence for a copper inhibition effect of PSII photoche- mistry. J. Photochem. Photobiol. 48: 329-332.

Samuelsson, G. and G. Öquist. - 1977. A method for studying photosynthetic capacities of unicellular algae based on in vivo fluorescence. Physiol. Plant 40: 315-319.

Satoh, M., E. Karaki, M. Kakehashi, E. Okazaki, T. Gotoh and Y. Oyama. - 1999. Heavy-metal induced changes in nonproteinaceous thiol levels and heavy-metal binding peptide in Tetraselmis tetrahele (Prasinophyceae). J. Phycol. 35: 989-994.

Scanlan, D.J., N.J. Silman, K.M. Donald, W.H. Wilson, N.G. Carr, I. Joint and N.H. Mann. - 1997. An immunological approach to detect phosphate stress in populations and single cells of photosynthetic picoplankton. Appl. Enivon. Microbiol. 63: 2411-2420.

Schnürer, J. and T. Rosswall. - 1982. Fluorescein diacetate hydrolysis as a measure of total microbial activity in soil and litter. Appl. Environ. Microbiol. 43: 1256-1261.

Setlow, R.B., P.A. Swenson and W.L. Carrier. - 1963. Thymine dimers and inhibition of DNA synthesis by ultraviolet irradiation of cells. Science 142: 1464-1465.

Smetacek, V. - 1985. Role of sinking in diatom life-history cycles: Ecological, evolutionary and geological significance. Mar. Biol. 84: 239-251.

Smith, D.S. and D.D. Kitts. - 1995. Enzyme immunoassay for the determination of domoic acid in mussel extracts. J. Agric. Food Chem. 43: 367-371.

Smith, G.J., R.C. Zimmerman and R.S. Alberte. - 1992. Molecular and physiological response of diatoms to variable levels of irradiance and nitrogen availability: Growth of Skeletonema costatum in simulated upwelling conditions. Limnol. Oceanogr. 37: 989-1007.

Stauber, J.L. and T.M. Florence. - 1987. Mechanism of toxicity of ionic copper and copper complexes to algae. Mar. Biol. 94: $511-519$

Steen, H.B. - 1991. Flow cytometry instrumentation. In: S. Demers (ed.): Particle Analysis in Oceanography. Proceedings of the NATO Advanced Study Institute on Individual Cell and Particle Analysis in Oceanography, Aquafredda, Italy, October 2130, 1990. Springer, Berlin. pp. 3-29.

Stockner, J.G. and N.J. Antia. - 1986. Algal picoplankton from marine and freshwater ecosystems: a multidisciplinary perspective. Can. J. Fish. Aquat. Sci. 43: 2472-2503.

Stoecker, D.K., R.R.L. Guillard and R.M. Kavee. - 1981. Selective predation by Favella ehrenbergii (Tintinnia) on and among dinoflagellates. Biol. Bull. Mar. Biol. Lab. (Woods Hole) 160: 136- 145

Tyrrell, R.M. - 1986. Repair of genetic damage induced by UV-B (290-320 nm) radiation. In: Worrest, R.C. and M.M. Caldwell (eds.), Stratospheric ozone reduction, solar ultraviolet radiation and plant life, pp. 139-149. NATO ASI Series G8. Springer, Berlin.

Veldhuis, M.J.W. and G.W. Kraay. - 2000. Application of flow cytometry in marine phytoplankton research: Current applications and future perspectives. Sci. Mar. 64(2): 121-134.

Villareal, T.A., M.A. Altabet and K. Culver-Rhymsza. - 1993. Nitrogen transport by vertically migrating diatom mats in the North Pacific Ocean. Nature 363: 709-712.

Waite, A.M., R.J. Olson, H.G. Dam and U. Passow. - 1995. Sugarcontaining compounds on the cell surfaces of marine diatoms measured using concanavalin A and flow cytometry. J. Phycol. 31: $925-933$

Yentsch, C.M., P.K. Horan, K. Muirhead, Q. Dortch, E. Haugen, L. Legendre, L.S. Murphy, M.J. Perry, D.A. Phinney, S.A. Pomponi, R.W. Spinrad, M. Wood, C.S. Yentsch and B.J. Zahuranec. - 1983. Flow cytometry and cell sorting: A technique for analysis and sorting of aquatic particles. Limnol. Oceanogr. 28: 1275-1280.

Yentsch, C.M., T.L. Cucci and F.C. Mague. - 1988. Profiting from the visible spectrum. Biol. Oceanogr. 6: 477-492.

Zettler, E.R., R.J. Olson, B.J. Binder, S.W. Chisholm, S.E. Fitzwater and R.M. Gordon. - 1996. Iron-enrichment bottle experiments in the Equatorial Pacific: Responses of individual phytoplankton cells. Deep-Sea Res. 43: 1017-1029. 